\title{
PENGEMBANGAN TEKNOLOGI TERINTEGRASI PADA KELOMPOK TANI MATTIROWALIE DAN SIPAKAINGE DI KECAMATAN KAHU KABUPATEN BONE
}

\author{
St. Rohani ${ }^{1}$, M.I. Said ${ }^{2}$ dan A. Kasirang ${ }^{3}$
}

\begin{abstract}
ABSTRAK
Implementasi hasil-hasil pengembangan penelitian di perguruan tinggi dapat dilakukan melalui kegiatan pengabdian masyarakat. Program pengabdian masyarakat dapat dilakukan melalui kegiatan introduksi teknologi. Program Pengabdian Masyarakat (PPM) dengan skim kegiatan Program Kemitraan Wilayah (PKW) merupakan salah satu wadah untuk mengimplementasikan teknologi-teknologi yang telah dikembangkan di perguruan tinggi. Tujuan kegiatan ini adalah untuk mengintroduksi teknologi dalam bidang peternakan dan pertanian bagi anggota kelompok peternak sapi di Kecamatan Kahu Kabupaten Bone. Sebanyak 2 aspek bidang telah diintroduksi dalam kegiatan ini yakni bidang peternakan dan pertanian. Dalam bidang peternakan meliputi : 1) teknologi pembuatan pakan fermentasi jerami, 2) pembuatan pakan penguat dalam bentuk Urea Molases Block (UMB), 3) teknologi proses produksi mikroorganisme lokal (MOL), 4) penyuluhan tentang nilai ekonomi usaha ternak sapi. Untuk aspek pertanian berupa teknik budidaya jamur tiram (Pleurotus ostreatus). Kegiatan ini dilaksanakan melalui kerjasama dengan Universitas Islam Makasssar (UIM) sebagai mitra perguruan tinggi. Kegiatan ini diikuti oleh 2 (dua) Kelompok, yakni Kelompok Tani Ternak (KTT) "MattirowaliE" dari Desa Cenrana dan KTT "Sipakainge" dari Desa Biru, Kec. Kahu, Kab. Bone. Kegiatan pelatihan diikuti oleh sekitar 30 orang. Hasil akhir dari pelaksanaan kegiatan adalah adanya peningkatan pengetahuan dan keterampilan dari para anggota mitra dalam mengembangkan usaha budidaya jamur tiram maupun mengolah limbah pertanian sebagai pakan ternak alternatif
\end{abstract}

Kata Kunci: produktivitas, pakan, fermentasi, introduksi, jamur tiram

\begin{abstract}
The implementation of the results of research development in universities can be done through community service activities. Community service programs can be carried out through technology introduction activities. Community Service Program (CSP) with a scheme of Program Kemitraan Wilayah (PKW) activities is one of the platforms for implementing technologies that have been developed in universities. The purpose of this activity is to introduce technology in the field of livestock and agriculture for members of the cattle farmers group in Kahu District, Bone Regency. As many as 2 aspects of the field have been introduced in this activity, namely the field of livestock and agriculture. In the field of livestock include: 1) technology for making straw fermented feed, 2) making reinforcing feed in the form of Urea Molases Block (UMB), 3) local microorganism (LM) production process technology, 4) counseling on the economic value of cattle livestock business. For the agricultural aspect in the form of techniques for cultivating oyster mushrooms (Pleurotus ostreatus). This activity was

\footnotetext{
${ }^{1}$ Dosen Departemen Sosial Ekonomi Peternakan, Fak.Peternakan Universitas Hasanuddin, Makassar nanirohani24@yahoo.co.id

${ }^{2}$ Dosen Departemen Produksi Ternak, Fak.Peternakan Universitas Hasanuddin, Makassar, irfanunhas@gmail.com

${ }^{3}$ Dosen Fak.Pertanian, Universitas Islam Makassar(UIM),Makassar, irabaso05@yahoo.com
} 
carried out in collaboration with Makasssar Islamic University as a university partner. This activity was attended by 2 (two) Groups, namely "Mattirowalie" Livestock Farmers Group from Cenrana Village and "Sipakainge" from Biru Village, Kahu District, Bone Regency. The training activities were attended by around 30 people. The final result of the implementation of the activity is an increase in the knowledge and skills of the partner members in developing the oyster mushroom cultivation business as well as processing agricultural waste as an alternative animal feed.

Keywords: productivity, feed, fermentation, introduction, oyster mushroom

\section{PENDAHULUAN}

Kegiatan program pengabdian masyarakat (PPM) merupakan salah satu tugas fungsi dari Tri Dharma Perguruan Tinggi. Kegiatan pengabdian masyarakat pada dasarnya merupakan implementasi dari pengembangan hasil-hasil penelitian yang telah dilakukan oleh dosen di Perguruan Tinggi. Kegiatan ini bertujuan untuk mengintroduksi beberapa teknologi sederhana dalam bidang peternakan dan pertanian bagi anggota kelompok peternak sapi di Kecamatan Kahu Kabupaten Bone.

Kecamatan Kahu, Kabupaten Bone merupakan wilayah yang berada pada posisi $\pm 60 \mathrm{~km}$ sebelah barat daya Kota Watampone, ibukota Kabupaten Bone. Wilayah ini berbatasan langsung dengan 5 kecamatan lain dalam wilayah Kabupaten Bone, yakni Kec. Libureng, Kec. Patimpeng, Kec.Salomekko, Kec.Kajuara dan Kec. Bontocani. Berdasarkan data sensus Tahun 2013, populasi ternak sapi potong khusus di wilayah sasaran (Kecamatan Kahu) mencapai 28.800 ekor (Disnak Kabupaten Bone, 2016). Populasi ini berada diurutan kedua populasi terbesar setelah Kecamatan Libureng.

Salah satu permasalahan pokok yang dihadapi oleh masyarakat peternakan di Kecamatan Kahu adalah masih rendahnya produktivitas ternak. Rendahnya produktivitas ternak disebabkan karena belum kontinunya suplai pakan, sedangkan daerah ini kaya dengan lahan pertanian khususnya persawahan. Potensi ketersediaan limbah pertanian seperti jerami tampaknya belum dimanfaatkan secara maksimal. Selain itu produksi limbah ternak juga belum sepenuhnya termanfaatkan sedangkan limbah ternak merupakan salah satu sumber hara bagi tanaman pertanian.

Kelompok Tani Ternak (KTT) "Mattirowalie" yang berada di Desa Cenrana dan KTT "Sipakainge" dari desa Biru merupakan dua kelompok peternakan sapi potong yang sangat aktif dalam pengembangan usaha budidaya ternak sapi potong. Sebagai implementasi dari beberapa permasalahan yang dihadapi Pemerintah Kabupaten Bone selama ini, maka terdapat beberapa kegiatan yang telah dilakukan sebagai sebuah tawaran solusi sesuai hasil kesepakatan antara pihak Pemerintah Daerah Bone dengan pihak Universitas Hasanuddin dalam hal ini tim dari Fakultas Peternakan Universitas Hasanuddin maupun mitra Universitas Islam Makassar.

Permasalahan yang terkait dengan aspek produksi dan manajemen merupakan permasalahan pokok yang dihadapi mitra. Belum maksimalnya upaya dalam memperbaiki kualitas, kuantitas serta kontinuitas pakan ternak yang diberikan selama proses budidaya merupakan salah satu permasalahan dalam bidang produksi. Pakan ternak merupakan kebutuhan urgen yang dibutuhkan dalam meningkatkan produktivitas ternak (Andang dan Indartono, 2014). Limbah peternakan yang selama ini banyak dihasilkan dari usaha pertanian juga belum dimanfaatkan secara maksimal (Pasaribu, 2017), sehingga hal tersebut sangat penting untuk diperhatikan.

Kegiatan introduksi teknologi ini merupakan salah satu program dari Kementerian Riset, Teknologi dan Pendidikan tinggi (Kemenristekdikti) melalui skim Program Kemitraan Wilayah $(\mathrm{PKW})$. Tujuan pelaksanaan program adalah: 1) mengintroduksi teknologi pada anggota mitra

\section{2 | BULETIN UDAYANA MENGABDI}


kelompok tani sebagai upaya meningkatkan produktivitas ternak 2) sebagai wujud kepedulian perguruan tinggi untuk mengaplikasikan dan mengembangkan hasil inovasi dan temuan.

\section{METODE PELAKSANAAN KEGIATAN}

Pelaksanaan kegiatan dilakukan secara bertahap, yakni : 1) Sosialisasi. Tujuan proses ini adalah untuk mengenalkan rencana kegiatan yang telah diprogram kepada mitra. 2) Identifikasi permasalahan. Tujuan tahapan ini adalah untuk mengidentifikasi dan mengetahui kondisi awal lapangan sebelum introduksi teknologi. Kegiatan berikutnya adalah 3) Pelatihan. Tujuan kegiatan ini adalah untuk menambah pengetahuan mitra melalui pemberian materi pelajaran dalam bentuk teori-teori yang sifatnya sederhana. 3) Praktek. Tahap ini bertujuan untuk lebih memudahkan mitra dalam mengadopsi inovasi teknologi yang telah diajarkan.

\section{HASIL DAN PEMBAHASAN}

\section{Sosialisasi}

Sosialisasi kegiatan dilakukan sebagai tahap awal kegiatan. Proses sosialisasi dilakukan secara bersamaan dengan proses identifikasi masalah yang berkembang dilapangan. Berdasarkan hasil identifikasi awal menunjukkan bahwa permasalahan ketersediaan pakan menjadi sebuah masalah pokok. Masalah ini senantiasa timbul pada musim-musim tertentu dimana ketersediaan hijauan menjadi sangat minim. Gambaran pelaksanaan kegiatan sosialisasi yang telah dilakukan dilokasi mitra secara lengkap disajikan pada Gambar 1.
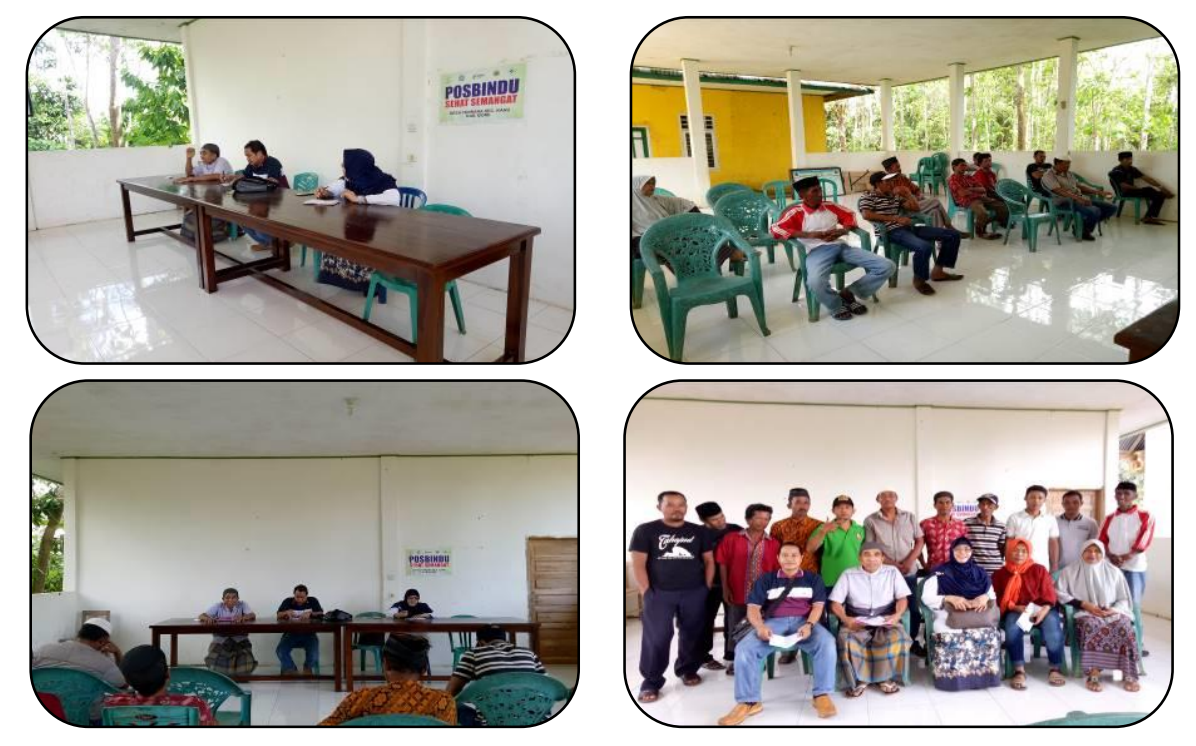

Gambar 1. Kegiatan sosialisasi kegiatan PKW pada Kelompok Tani/Ternak (KTT) "Mattirowalie" (Desa Cenrana) dan KTT "Sipakainge" (Desa Biru) yang dipusatkan di Desa Cenrana, Kec.Kahu, Kab. Bone

\section{Identifikasi Masalah}

Kegiatan identifikasi masalah dilakukan dengan tujuan untuk memperoleh kondisi ril lapangan dan menemukan solusi yang dihadapi para peternak. Gambaran kegiatan identifikasi masalah secara lengkap disajikan pada Gambar 2.

Berdasarkan hasil identifikasi masalah diperoleh beberapa informasi terkait permasalahan di lapangan. Limbah jerami yang banyak tersedia di kandang peternak hanya diberikan dalam bentuk mentah tanpa diolah. Hal ini menyebabkan jerami tersebut sulit sekali 
dicerna oleh ternak. Selain itu nilai nutrisi pada pakan tersebut juga sangat rendah juga sangat rendah.
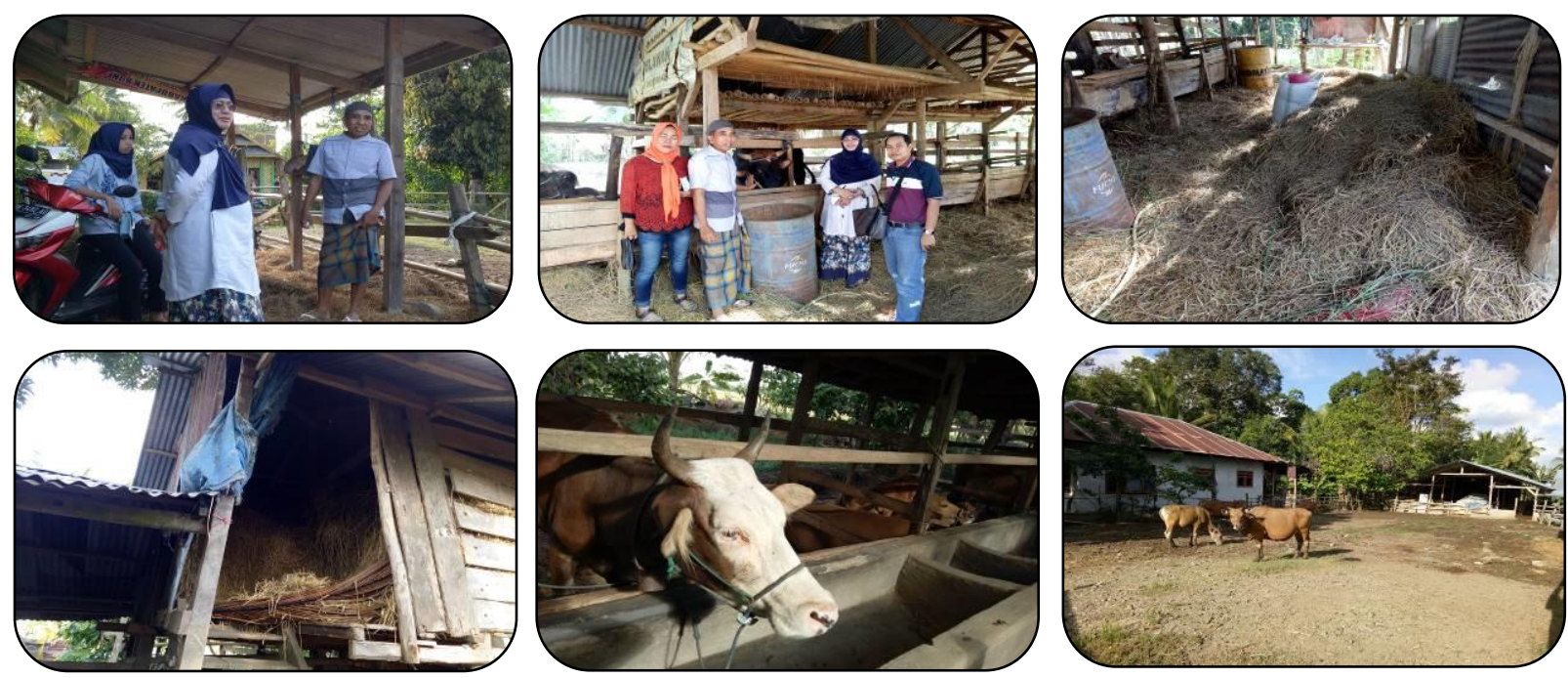

Gambar 2. Kegiatan identifikasi lapangan pada Kelompok Tani/Ternak (KTT) "Mattirowalie" (Desa Cenrana) dan KTT "Sipakainge" (Desa Biru)

Di Kec. Kahu, Kab. Bone

\section{Kegiatan Pelatihan}

Untuk meningkatkan pemahaman mitra kelompok tani maupun aparat pemerintah daerah tentang aplikasi teknologi, maka sebelumnya dilakukan peningkatan kapasitas yang diimplementasikan dalam bentuk pelatihan. Dalam pelatihan tersebut diikuti oleh sejumlah mitra kelompok tani, kepala desa pemerintah daerah (dinas peternakan). Dokumentasi kegiatan pelatihan secara lengkap disajikan pada Gambar 3.

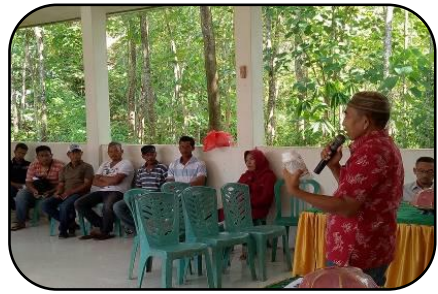

a

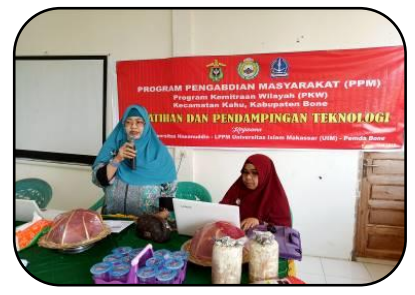

b

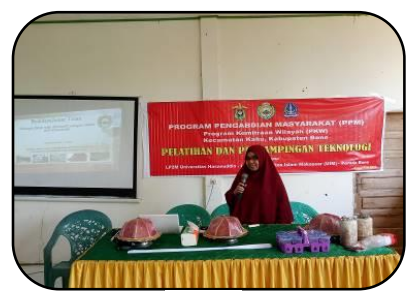

c

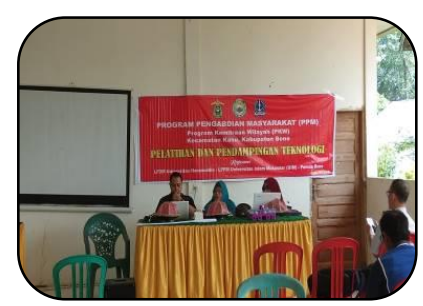

d

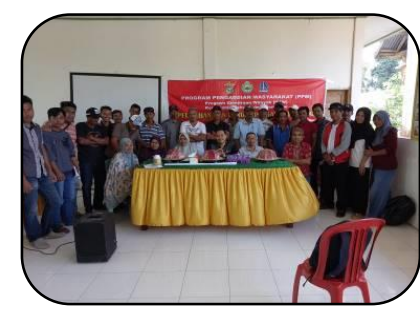

e

Gambar 3. Kegiatan pelatihan dalam kegiatan PKW pada anggota Kelompok

Tani/Ternak (KTT) "Mattirowalie" (Desa Cenrana) dan KTT "Sipakainge"

(Desa Biru) Di Kec. Kahu, Kab. Bone 
Kegiatan pelatihan dimulai dengan acara pembukaan oleh Bapak Kamaruddin (a) sebagai Petugas Penyuluh Lapangan (PPL) Kecamatan Kahu sebagai wakil dari Pemerintah Daerah Bone. Dilanjutkan dengan pemaparan materi oleh Dr.Ir.Hj.St.Rohani, M.Si (Ketua Pelaksana) (b) terkait dengan potensi ekonomi dan manajemen pembukuan kelompok. Selanjutnya oleh Dr. Andi Kasirang, S.P, M.Si (c) memaparkan tentang teknologi budidaya jamur tiram dan Dr.Muhammad Irfan Said, S.Pt, M.P (d) memberikan materi tentang teknologi pengolahan pakan ternak dan pengolahan limbah. Selain itu juga diberikan materi terkait dengan teknologi pembuatan Mikroorganisme lokal (MOL) sebagai dekomposer fermentasi alami. Penggunaan MOL akhir-akhir ini banyak dipertimbangkan oleh para peneliti mengingat MOL merupakan sumber mikroorganisme yang murah, mudah diperoleh dan dikembangkan serta ramah lingkungan. Mol dapat diperoleh dari hewani maupun dari nabati (Said, 2014) Pelaksanaan kegiatan ini dihadiri oleh sekitar 30 orang petani/peternak yang tergabung dalam 2 kelompok tani/ternak sasaran, yakni Kelompok Tani/Ternak (KTT) "Mattirowalie" dari Desa Cenrana dan KTT "Sipakainge” dari Desa Biru.

\section{Kegiatan Praktek Lapangan}

Untuk meningkatkan pemahaman mitra terkait teknologi yang diintroduksikan, maka perlu dilakukan kegiatan praktek seperti pada Gambar 4.

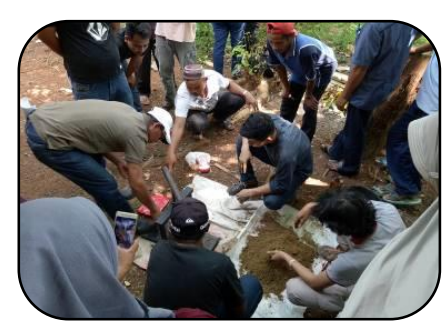

a

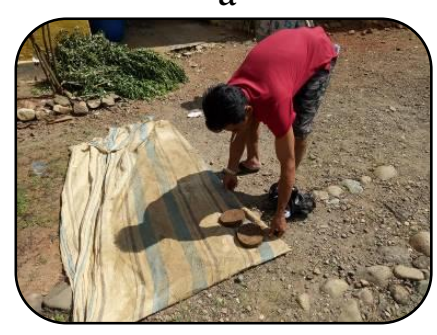

d

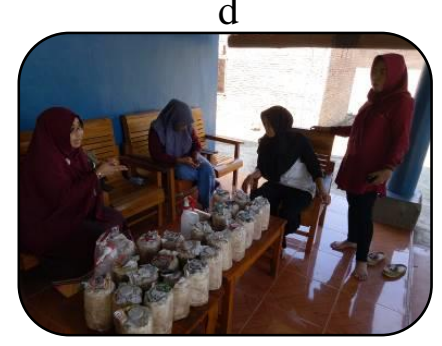

g

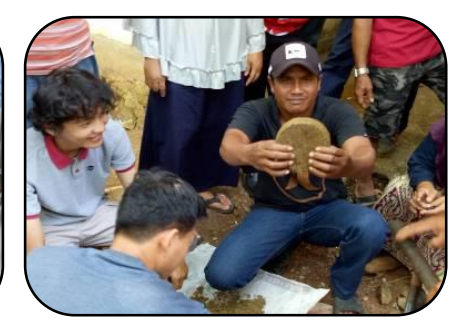

b

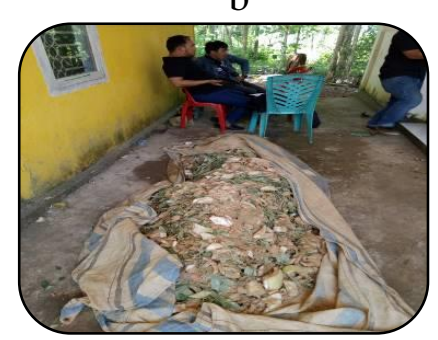

$\mathrm{e}$

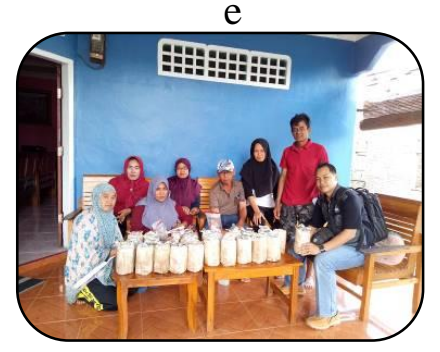

h

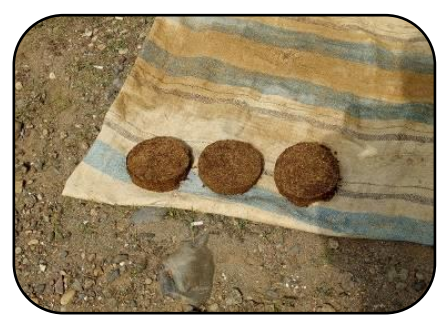

c

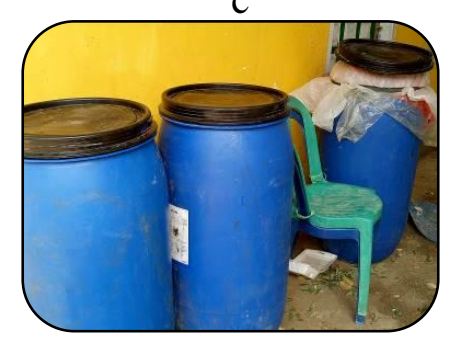

f

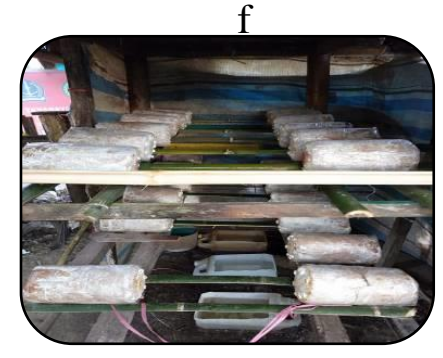

i

Gambar 4. Kegiatan praktek lapangan pembuatan pakan pakan suplemen UMB dan pakan fermentasi dan budidaya jamur tiram pada pada pada anggota Kelompok Tani/Ternak (KTT) "Mattirowalie" (Desa Cenrana) dan KTT "Sipakainge" (Desa Biru) Di Kec. Kahu, Kab. Bone 
Beberapa kegiatan yang dilakukan dalam mengintroduksi teknologi kepada petani peternak. Salah satunya adalah pembuatan pakan suplemen Urea Molases Blok (UMB) (a-d). Selanjutnya pembuatan pakan silase fermentasi menggunakan bahan baku batang pisang (e-f). Kegiatan berikutnya adalah teknik budidaya jamur tiram hingga pembuatan demplot jamur tiram (g-i). UMB merupakan pakan tambahan atau suplemen yang sangat bermanfaat dalam meningkatkan produktivitas ternak sapi. Bahan baku UMB salah satunya adalah pupuk urea bermanfaat sebagai sumber Nitrogen Non-Protein (NPN) yang digunakan dalam proses fermentasi oleh mikroba dalam rumen. Pakan suplemen ini dapat diberikan pada ternak yang gembalakan ataupun yang dikandangkan (Prasetyono, 2014).

\section{KESIMPULAN}

1. Introduksi teknologi peternakan dan pertanian merupakan kegiatan yang bersifat integrasi

2. Kegiatan introduksi teknologi memberikan pengetahuan yang lebih banyak bagi mitra untuk memanfaatkan sumber daya alam bagi kesejahteraan mereka

3. Program introduksi teknologi mendapat respon yang sangat baik dari pihak pemerintah daerah Bone maupun dari mitra kelompok tani

\section{UCAPAN TERIMA KASIH}

Tim pelaksana mengucapkan terima kasih yang setinggi-tingginya kepada Kementerian Riset, Teknologi dan Pendidikan Tinggi, Rektor Universitas Hasanuddin, Ketua Lembaga Penelitian dan Pengabdian Kepada Masyarakat (LP2M) Universitas Hasanuddin atas dukungan pendanaan kegiatan melalui Program Pengabdian Masyarakat (PPM) dengan skim Program Kemitraan Wilayah (PKW) serta Pemerintah Kabupaten Bone dan mitra kelompok tani/ternak "Mattirowalie" (Desa Cenrana) dan KTT “Sipakainge” (Desa Biru) Di Kec. Kahu, Kab. Bone

\section{DAFTAR PUSTAKA}

Andang, S dan Indartono. 2014. Teknologi Pakan untuk Sapi Perah, Jakarta

Disnak Kabupaten Bone. 2016. Kabupaten Bone dalam Angka 2016.

$$
\text { https://bone.go.id/2017/09/22/kabupaten-bone-dalam-angka-2017/ }
$$

Pasaribu, T. 2007. Produk fermentasi limbah pertanian sebagai bahan pakan unggas di indonesia. Jurnal Wartazoa. Vol. 17 (3) : 109-116.

Prasetyono, R.C. 2014. Teknik Pengolahan UMB (Urea Molases Blok) Untuk Ternak Ruminansia. Balai Pengkajian Teknologi Pertanian Kepulauan Riau. Badan Penelitian dan Pengembangan Pertanian. Kementerian Pertanian, Jakarta.

Said, M.I. 2014. By Product Ternak. Teknologi dan Aplikasinya. IPB Press, Bogor. 